\title{
KURS DAN NILAI PERDAGANGAN SAHAM DI BEI SEBELUM DAN PADA MASA PANDEMI COVID-19
}

\author{
Penta Widyartati ${ }^{1}$, Ira Setiawati ${ }^{2}$, Ariyani Indriastuti ${ }^{3}$ \\ 1,3) Sekolah Tinggi Ilmu Ekonomi Semarang \\ 2 ) Universitas PGRI Semarang
}

\begin{abstract}
Corona Virus (Covid-19) not only harms humans in terms of health, but also has a big impact on the world economy. This study aims to analyze the impact caused by the covid-19 outbreak on the value of securities trading on the IDX and the rupiah exchange rate against the USD. The study was conducted through two stages, the first was to test the effect of the independent and dependent variables. The dependent variable in this study is the trade value, namely the daily trading value data on the Indonesia Stock Exchange from December 2019 to May 2020. As for the exchange rate variable as an independent variable, the data is taken on the BI page. The data is divided into two, namely data before the pandemic, represented by trade data from December 2019 to February 2020, and data during the pandemic period represented by trade data from March 2020 to May 2020. After testing the relationship between dependent and independent variables, research followed by a comparison, which compares the effect of the exchange rate on the value of trade on the IDX before the pandemic and during the pandemic. The results showed that there was a significant relationship between the exchange rate and the value of trade during the observation period before the pandemic, but in the event of a pandemic, this significant relationship no longer exists.

Keywords : comparison; exchange rate; pandemic; trade value;

Correspondence to : pentawidyartati@gmail.com
\end{abstract}

\begin{abstract}
ABSTRAK
Virus Corona (Covid-19) tidak hanya merugikan manusia dari segi kesehatan, tetapi juga berdampak besar bagi perekonomian dunia. Penelitian ini bertujuan untuk menganalisis dampak wabah Covid-19 terhadap nilai perdagangan efek di BEI dan kurs rupiah terhadap USD. Penelitian dilakukan melalui dua tahap, yang pertama adalah menguji pengaruh variabel independen dan dependen. Variabel dependen dalam penelitian ini adalah nilai perdagangan yaitu data nilai perdagangan harian di Bursa Efek Indonesia dari Desember 2019 hingga Mei 2020. Sedangkan untuk variabel kurs sebagai variabel independen data diambil dari laman BI. Data tersebut terbagi menjadi dua, yaitu data sebelum pandemi yang diwakili oleh data perdagangan bulan Desember 2019 hingga Februari 2020, dan data selama periode pandemi diwakili oleh data perdagangan dari bulan Maret 2020 hingga Mei 2020. Setelah dilakukan pengujian hubungan antara variabel dependen dan independen, penelitian dilanjutkan dengan perbandingan, yaitu membandingkan pengaruh kurs terhadap nilai perdagangan di BEI sebelum pandemi dan saat pandemi. Hasil penelitian menunjukkan bahwa terdapat hubungan yang signifikan antara kurs dan nilai perdagangan selama periode observasi sebelum pandemi, namun pada saat terjadi pandemi, hubungan yang signifikan tersebut tidak ada lagi.
\end{abstract}

Kata Kunci : pandemi; perbandingan; kurs; nilai perdagangan.

\section{Riwayat Artikel:}

Received : 18 Juli 2020

Revised : 01 Januari 2021

Accepted : 22 Januari 2021 


\section{PENDAHULUAN}

Pasar modal memiliki fungsi ekonomi dan fungsi keuangan yang merupakan leading Indicator bagi perekonomian suatu negara. Perekonomian suatu negara dapat ditentukan melalui kebijakan moneter, salah satu mekanisme kebijakan moneter adalah penetapan suku bunga dan nilai tukar. Suku bunga merupakan salah satu variabel yang senantiasa diamati secara cermat karena dampaknya yang luas pada kesehatan perekonomian mulai dari segi konsumsi, kredit, obligasi, serta tabungan (M. Fauzan \& Suhendro, 2018; Munawaroh \& Handayani, 2019). Pada beberapa decade saat ini, pasar modal merupakan salah satu instrumen yang sangat penting dalam perekonomian Indonesia dan dunia. Kondisi pasar modal dapat dilihat melalui pertumbuhan indeks harga saham. Indeks harga saham merupakan salah satu indicator atau cerminan dari pergerakan harga saham pada satu periode. Pasar modal merupakan salah satu alternaif untuk menjembatani hubungan antara pemilik modal dalam hal ini disebut pemodal (investor) dengan pihak yang membutuhkan dana yang disebut emiten (perusahaan yang go publik). Pasar modal memiliki peran menyediakan sumber dana alternative jangka panjang bagi perusahaan sehingga dapat mengurangi ketergantungan pembiayaan investasi dari kredit perbankan baik dari dalam negeri maupun luar negeri.

Hasil penelitian yang dilakukan (M. Fauzan \& Suhendro, 2018), menunjukkan bahwa secara umum menunjukkan bahwa kurs rupiah dan right issue secara bersama-sama berpengaruh terhadap harga saham PT. Telekomunikasi Indonesia Tbk. Pengaruh Nilai Tukar terhadap Harga saham menurut Eduardus Tandelilin (2010) "Nilai tukar merupakan sinyal positif, artinya jika nilai tukar terapresiasi maka harga saham akan meningkat begitu juga sebaliknya jika nilai tukar mengalami depresiasi maka harga saham akan mengalami penurunan" Penelitian tentang pengaruh nilai tukar terhadap harga saham juga telah dilakukan oleh (Ratna, Topowijono, \& Sulasmiyati, 2016) menyatakan bahwa "Nilai tukar terdapat pengaruh negative dan tidak signifikan terhadap harga saham". Sensitifitas pasar modal tampak ketika terjadi fenomena fluktuasi kurs mata uang domestik. Fluktuasi kurs yang tidak terkendali akan mempengaruhi kinerja badan usaha di pasar modal yang akan berdampak pada pergerakan harga saham.

Dalam masa pandemi seperti sekarang ini, kurs rupiah mengalami fluktuasi yang sangat tinggi. Fluktuasi tersebut seringkali berupa fluktuasi negatif atau penurunan penurunan nilai mata uang. Penurunan nilai mata uang suatu negara, atau disebut juga sebagai pelemahan mata uang, mengakibatkan sentimen negatif terhadap perdagangan surat berharga pada negara yang bersangkutan. Sentimen negatif adalah suatu pergerakan yang begitu kuat yang dapat melemahkan pasar.

Pelemahan nilai mata uang rupiah dapat disebabkan berbagai hal antara lain adanya suatu kejadian ataupun bencana di suatu negara. Hal ini juga terjadi di Indonesia, yang juga terdampak covid 19. Indonesia dinyatakan positif covid 19 pada bulan Maret 2020.

Dampak corona terhadap perekonomian dunia sangat menghawatirkan, banyak negara yang sudah menutup diri atau lockdown sehingga menghentikan sejumlah aktivitas perekonomian. Penghentian sejumlah aktivitas terpaksa dilakukan sebagai upaya antisipasi merebaknya virus yang semakin cepat walaupun dengan konsekuensi terhambatnya perekonomian.

Pandemi yang merebak sejak awal Maret 2020 yang mengakibatkan berbagai dampak ekonomi di Indonesia menarik perhatian peneliti untuk melakukan penelitian 
mengenai perdagangan di pasar modal Indonesia yaitu BEI. Penelitian ini bertujuan mengetahui perbedaan pengaruh antara kurs rupiah terhadap nilai perdagangan saham pada rentang waktu sebelum dan selama pandemi Covid 19 dan menganalisis penyebabnya.

Dalam penelitian-penelitian yang sudah dilakukan, hampir semua literatur menunjukkan adanya pengaruh yang signifikan antara kurs rupiah terhadap perdagangan saham di BEI. Dari literatur dengan variabel dependen IHSG, semua penelitian juga menunjukkan adanya pengaruh kurs rupiah terhadap IHSG. IHSG merupakan merupakan indeks yang paling banyak digunakan dan dipakai sebagai acuan tentang perkembangan kegiatan di pasar modal. Penelitian dilakukan oleh (Palatte \& Akbar, 2014) dengan periode penelitian 2009-2013, (Firhan \& Suhadak, 2019) periode penelitian 2013-2017, (Kewal, 2012) periode penelitian 2000-2009, (Sudirman, 2018) periode penelitian 2010, (Nidianti \& Wijayanto, 2019) periode penelitian 2014-2017, (Ika Alivia Rizky, 2019) periode penelitian 2015-2017, (Ardelia Rezeki Harsono \& Worokinasih, 2018) periode penelitian 2013 sampai 2017, (Mifta Indriati, Vaya Juliana Dillak , \& Zulistina., 2019) periode penelitian 2009 sampai 2018. Dari semua penelitian di atas menunjukkan adanya hubungan yang signifikan antara kurs terhadap pergerakan IHSG. Adapun penelitian yang menunjukkan adanya hubungan yang tidak signifikan antara kurs dengan IHSG adalah penelitian yang dilakukan oleh (Setiawan \& Mulyani, 2020) yang dilakukan pada periode 2014 sampai 2018.

Kebaharuan dalam penelitian ini adalah pada metode yang digunakan, yaitu metode kualitatif komparasi, sedangkan yang dikomparasikan dalam penelitian ini adalah dari hasil pengujian kuantitatif dengan regresi sederhana menggunakan program Eviews. Sedangkan data yang dikomparasikan adalah data kurs rupiah terhadap nilai perdagangan efek di BEI sebelum dan pada masa pandemi Covid-19.

\section{METODE PENELITIAN}

Pada dasarnya, penelitian ini merupakan jenis penelitian deskriptif komparatif yang membandingkan pengaruh kurs terhadap nilai perdagangan saham sebelum pandemi dan selama masa pandemi. Dengan membandingkan pengaruh, maka hal yang pertama kali dilakukan dalam penelitian ini adalah mencari pengaruh kurs terhadap nilai perdagangan saham sebelum dan selama masa pandemi. Kemudian hasil pengujian diperbandingkan. Setelah itu dilakukan analisis yang menjadi penyebab perbedaan pengaruh tersebut. Populasi dalam penelitian ini adalah nilai perdagangan efek di BEI serta kurs Rupiah terhadap USD dengan sampel periode Desember 2019 hingga Mei 2020. Sampel data selama 6 bulan dibagi menjadi dua, yaitu data sebelum pandemi (Desember 2019 sampai dengan Februari 2020) dan data pada masa pandemi (Maret 2020 sampai dengan Mei 2020). Alasan pengambilan sampel tersebut karena disesuaikan dengan tujuan penelitian yaitu untuk mengetahui pengaruh kurs terhadap volume dan nilai perdagangan sebelum dan sesudah pandemi.

Penelitian dapat digambarkan dalam kerangka pemikiran sebagai berikut: 


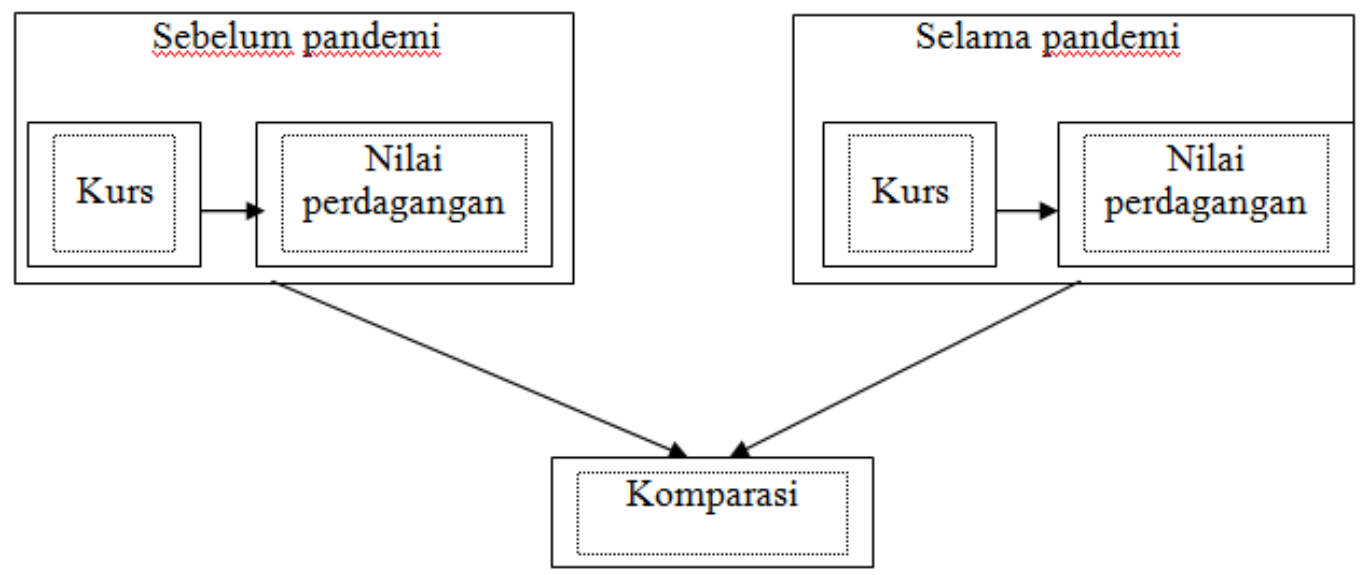

Gambar 1. Kerangka Pemikiran

Variabel dalam penelitian ini meliputi kurs dan nilai perdagangan di BEI. Sumber data yang digunakan dalam penelitian ini adalah data sekunder yang bersumber dari www.idx.com untuk variabel nilai perdagangan dengan obyek penelitian semua perusahaan yang terdaftar di BEI, dan dari www.bi.go.id untuk variabel kurs. Data sekunder merupakan sumber data penelitian yang diperoleh peneliti secara tidak langsung melalui media perantara atau diperoleh dan dicatat oleh pihak lain (Indriantoro, 1999). Metode pengumpulan data yang digunakan dengan cara studi dokumentasi berupa dokumen rekapitulasi perdagangan harian di laman www.idx.com untuk variabel nilai perdagangan dan kalkulasi kurs tengah harian di laman www.bi.go.id untuk variabel kurs. Kurs yang dimaksud dalam penelitian ini adalah nilai pertukaran rupiah terhadap USD dan kurs yang digunakan adalah kurs tengah.

\section{HASIL PENELITIAN}

Pengujian data sebelum pandemi

Dalam penelitian ini mula-mula data dianalisis secara terpisah antara data sebelum pandemi dan selama pandemi. Ringkasan data nilai perdagangan dan kurs rupiah terhadap USD sebelum pandemi ditampilkan dalam tabel sebagai berikut:

TABEL 1. Ringkasan data nilai perdagangan dan kurs sebelum pandemi (Desember 2019 s/d Februari 2020)

Descriptive Statistics

\begin{tabular}{lllllll}
\hline & N & Minimum & Maximum & Sum & Mean & $\begin{array}{l}\text { Std } \\
\text { Deviation }\end{array}$ \\
\hline Nilai & 61 & $4,17 \mathrm{E} 12$ & $1,32 \mathrm{E} 13$ & $4,29 \mathrm{E} 14$ & $7,0250 \mathrm{E} 12$ & $1,56886 \mathrm{E} 12$ \\
\hline Kurs & 61 & 9085,00 & 9753,00 & 574332,00 & 9415,2787 & 207,32512 \\
\hline $\begin{array}{l}\text { Valid N } \\
\text { (listwise) }\end{array}$ & & & & & & \\
\hline \multicolumn{2}{l}{ Sumber: data diolah penulis (2020) }
\end{tabular}




\section{Sedangkan pergerakan nilai} perdagangan dan kurs dari 61 data pengamatan ditampilkan dalam grafik sebagai berikut:

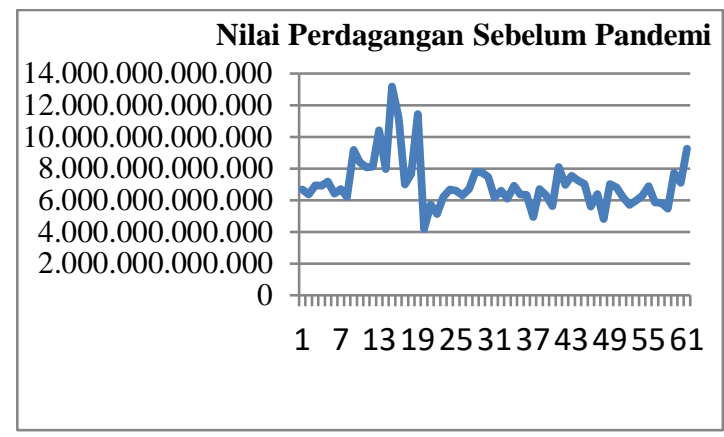

Gambar 1. Grafik Nilai perdagangan sebelum pandemi (Desember 2019 s/d Februari 2020)

Sumber: data diolah penulis (2020)

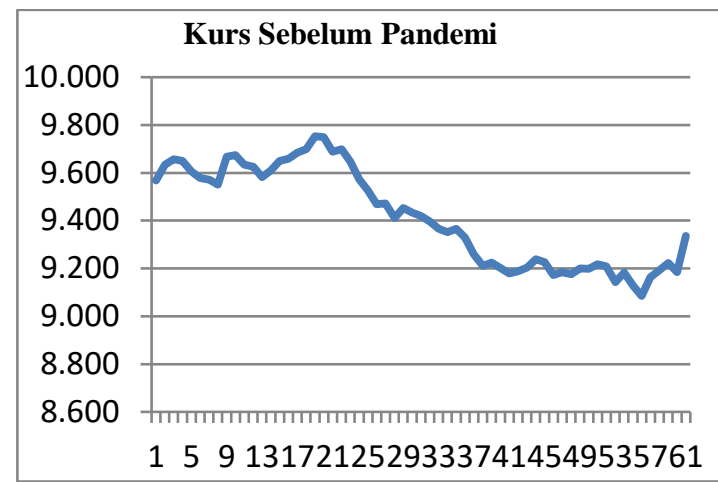

Gambar 2. Grafik Kurs sebelum pandemi (Desember 2019 s/d Februari 2020)

Sumber: data diolah penulis (2020)

Kemudian dari data nilai perdagangan harian dan kurs harian dilakukan pengujian pengaruh dengan menggunakan program Eviews 9. Output pengujian ditampilkan dalam tabel sebagai berikut:

TABEL 2. Output Regresi Sederhana Pengaruh Kurs Terhadap Nilai Perdagangan Sebelum Pandemi (Desember 2019 s/d Februari 2020)

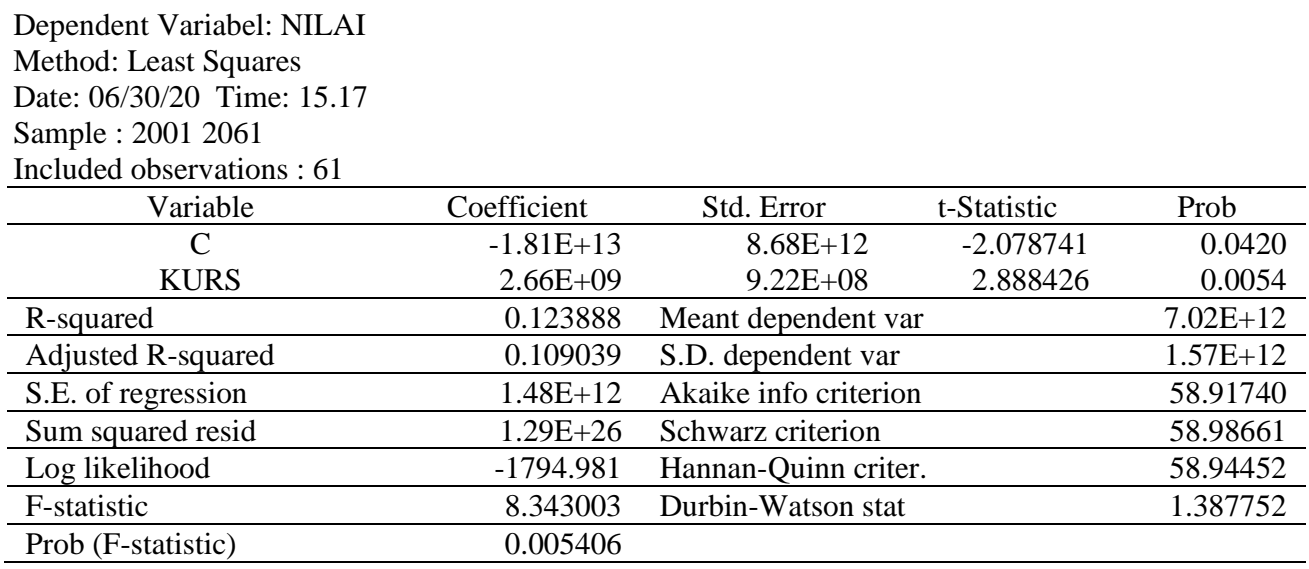

Sumber: Output eviews (2020)

\section{Pengujian data selama pandemi}

Ringkasan data nilai perdagangan dan kurs rupiah terhadap USD selama pandemi ditampilkan dalam tabel sebagai berikut: 
TABEL 3. Ringkasan data nilai perdagangan dan kurs selama pandemi (Maret 2019 s/d Mei 2020)

\begin{tabular}{lrrrrrr}
\hline & N & Minimum & Maximum & Sum & Mean & $\begin{array}{r}\text { Std } \\
\text { Deviation }\end{array}$ \\
\hline Nilai & 58 & $5,18 \mathrm{E} 12$ & $4,04 \mathrm{E} 13$ & $4,67 \mathrm{E} 14$ & $8,0551 \mathrm{E} 12$ & $4,88670 \mathrm{E} 12$ \\
\hline Kurs & 58 & 14168,00 & 16741,00 & 8900959,00 & 15361,3621 & 737,16574 \\
\hline $\begin{array}{l}\text { Valid N } \\
\text { (listwise) }\end{array}$ & 58 & & & & & \\
\hline
\end{tabular}

Sumber: data diolah penulis (2020)

Sedangkan pergerakan nilai perdagangan dan kurs dari 58 data pengamatan ditampilkan dalam grafik sebagai berikut:

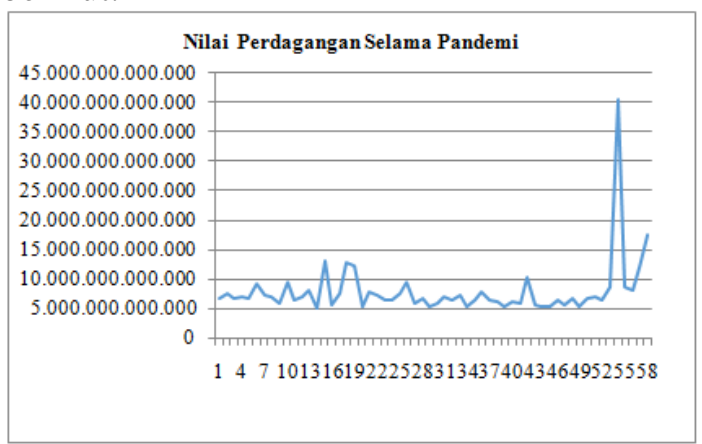

Gambar 3 Grafik Nilai perdagangan selama pandemi

(Maret 2020 s/d Mei 2020)

Sumber: data diolah penulis (2020)

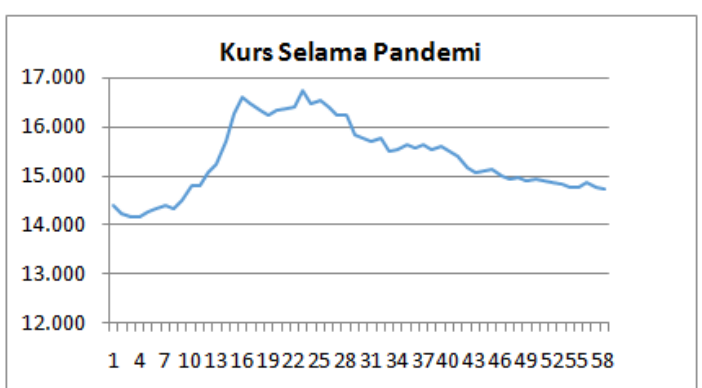

Gambar 4. Grafik Kurs selama pandemi (Maret 2020 s/d Mei 2020)

Sumber: data diolah penulis (2020)

Kemudian dari data nilai perdagangan harian dan kurs harian dilakukan pengujian pengaruh dengan menggunakan program Eviews 9. Output pengujian ditampilkan dalam tabel sebagai berikut:

TABEL 4. Output Regresi Sederhana Pengaruh kurs terhadap nilai perdagangan selama pandemi (Maret 2020 s/d Mei 2020)

\begin{tabular}{lcccc}
\hline \multicolumn{1}{c}{ Variable } & Coefficient & Std. Error & t-Statistic & Prob \\
\multicolumn{1}{c}{ C } & $1.74 \mathrm{E}+13$ & $1.36 \mathrm{E}+13$ & 1.286087 & 0.2037 \\
& $-6.11 \mathrm{E}+08$ & $8.82 \mathrm{E}+08$ & -0.693056 & 0.4911 \\
\hline R-squared & 0.008504 & Meant dependent var & $8.06 \mathrm{E}+12$ \\
\hline Adjusted R-squared & -0.009201 & S.D. dependent var & $4.89 \mathrm{E}+12$ \\
\hline S.E. of regression & $4.91 \mathrm{E}+12$ & Akaike info criterion & 61.31598 \\
\hline Sum squared resid & $1.35 \mathrm{E}+27$ & Schwarz criterion & 61.38703 \\
\hline Log likelihood & -1776.164 & Hannan-Quinn criter. & 61.34366 \\
\hline F-statistic & 0.480326 & Durbin-Watson stat & 1.771773 \\
\hline Prob (F-statistic) & 0.491139 & & \\
\hline
\end{tabular}

Sumber : Output Eviews (2020) 


\section{PEMBAHASAN}

Hasil dari pengujian di atas maka dapat diringkas sebagai berikut:

TABEL 5. Ringkasan data dan pengujian

\begin{tabular}{lrr}
\hline \multicolumn{1}{c}{ Keterangan } & \multicolumn{1}{c}{$\begin{array}{l}\text { Sebelum } \\
\text { pandemi }\end{array}$} & \multicolumn{1}{c}{$\begin{array}{c}\text { Selama } \\
\text { pandemi }\end{array}$} \\
\hline Prob & 0.0054 & 0.4911 \\
\hline Jumlah nilai & $4.29 \mathrm{E} 14$ & $4,67 \mathrm{E} 14$ \\
\hline Nilai maksimum & $1,32 \mathrm{E} 13$ & $4,04 \mathrm{E} 13$ \\
\hline Nilai minimum & $4.17 \mathrm{E} 12$ & $5,18 \mathrm{E} 12$ \\
\hline Rata-rata nilai & $7.0250 \mathrm{E} 12$ & $8,0551 \mathrm{E} 12$ \\
\hline Kurs minimal & 9.085 & 14.168 \\
\hline Kurs maksimal & 9.753 & 16.741 \\
\hline Kurs rata-rata & 9.415 & 15.361 \\
\hline
\end{tabular}

Sumber: data diolah penulis (2020)

Dari tabel di atas menunjukkan bahwa ada fenomena yang menarik yang terjadi dalam perdagangan saham selama pandemi. Hal tersebut adalah:

\section{Probabilitas}

Probabilitas yang diperoleh dari pengujian menggunakan Eviews 9 yang menguji pengaruh antara kurs dengan nilai perdagangan menunjukkan bahwa ada kurs mempengaruhi nilai perdagangan sebelum pandemi yang ditunjukkan dengan angka probabilitas sebesar 0,000 di bawah 0,05 , tetapi hal ini tidak terjadi pada masa pandemi yang ditunjukkan dengan angka probabilitas sebesar 0,491 atau di atas 0,05. Hal ini menunjukkan bahwa pandemi memberi dampak pada hubungan kurs terhadap nilai perdagangan.

Hampir semua penelitian yang menjadi referensi penelitian ini menunjukkan adanya pengaruh signifikan antara kurs dan nilai perdagangan efek di BEI. Perdagangan saham dalam beberapa literatur diwakili oleh IHSG. Menurut Parlette (2014) Indeks Harga Saham Gabungan (IHSG) merupakan indeks yang paling banyak digunakan dan dipakai sebagai acuan tentang perkembangan kegiatan di pasar modal.

Hasil pengujian yang pertama yaitu pengaruh kurs terhadap nilai perdagangan sebelum pandemi didukung oleh penelitian yang dilakukan oleh (Firhan \& Suhadak, 2019) yang menguji hubungan depresiasi rupiah terhadap perdagangan pasar modal. Dalam penelitiannya disebutkan bahwa depresiasi rupiah berpengaruh positif signifikan terhadap perdagangan pasar modal. Penelitian yang dilakukan oleh (Palatte \& Akbar, 2014) juga mengungkapkan hal yang senada, yaitu nilai tukar mata uang dan tingkat suku bunga berpengaruh terhadap IHSG. Hal serupa juga dituliskan dalam penelitian yang dilakukan oleh (Kewal, 2012) dalam penelitiannya, yang menguji pengaruh inflasi, kurs dan pertumbuhan PDB terhadap indeks harga saham gabungan mengatakan bahwa hanya kurs yang berpengaruh signifikan terhadap IHSG di BEI. Hal yang sama juga dinyatakan dalam penelitian (Sudirman, 2018) yang mengatakan bahwa perubahan nilai tukar rupiah tengah US Dollar berpengaruh terhadap Indeks Harga Saham Gabungan di BEI selama periode yang diteliti (2010-2015). Dalam penelitian yang dilakukan oleh (Nidianti \& Wijayanto, 2019) juga menyatakan bahwa kurs dan BI rate berpengaruh signifikan terhadap IHSG periode 2014-2017. Penelitian serupa juga dilakukan oleh (Ika Alivia Rizky, 2019) dengan hasil yang serupa, hasil uji parsial menunjukkan bahwa kurs, sertifikat Bank Indonesia, Inflasi dan tingkat GDP berpengaruh terhadap pergerakan IHSG pada BEI. Studi dilakukan pada tahun 2015-2017. Penelitian ini juga didukung oleh (Mifta Indriati et al., 2019) yang mengatakan bahwa tingkat suku bunga berpengaruh dengan arah negatif terhadap IHSG. Studi dilakukan pada BEI tahun 2009-2018.

Beberapa literatur penelitian yang digunakan sebelum terjadi pandemi menunjukkan adanya hubungan yang signifikan antara kurs dan perdagangan surat berharga di BEI. Hanya penelitian ini yang dilakukan dengan menggunakan data saat pandemi yang menunjukkan tidak adanya pengaruh signifikan antara kurs dan nilai perdagangan di BEI. Penelitian ini menarik karena menunjukkan besarnya pengaruh pandemi sehingga dapat mengubah pengaruh yang sebelumnya signifikan menjadi tidak signifikan. (Sari, 2019) dalam penelitiannya juga mengatakan bahwa Inflasi, suku bunga SBI, nilai tukar dan return LQ 45 berpengaruh 
signifikan terhadap IHSG. Intan juga menjelaskan bahwa IHSG merupakan cerminan dari kegiatan pasar modal secara umum. (Munawaroh \& Handayani, 2019) dalam penelitiannya juga mengatakan bahwa kurs rupiah berpengaruh terhadap IHSG.

\section{Jumlah Nilai Perdagangan}

Nilai perdagangan pada masa sebelum pandemi adalah sebesar 4,29E14, sedangkan nilai perdagangan selama pandemi justru mengalami peningkatan yaitu menjadi sebesar 4,67E14.

Kenaikan nilai perdagangan ini juga bisa diakibatkan karena optimistis pada pasar dalam negeri. Dengan adanya pandemi yang mengakibatkan melemahnya kurs rupiah mengakibatkan mahalnya barang-barang impor. Dengan mahalnya barang-barang impor dan melemahnya impor akan mempermudah perusahaan dalam negeri untuk menguasai pasar. Untuk itu perlu dilakukan penelitian lebih lanjut untuk meneliti dampak covid 19 terhadap perusahaan yang berorientasi pada ekspor dan impor.

Hal ini juga sangat menarik karena dalam kondisi dengan fenomena covid 19 yang memukul perekonomian pada banyak sektor, tetapi justru nilai perdagangan surat berharga di BEI lebih tinggi dari saat pada masa pengamatan sebelum terjadi pandemi.

Nilai maksimum perdagangan

Nilai maksimum adalah transaksi harian tertinggi dalam masa sebelum dan selama pandemi. Dari tabel distrbusi frekuensi, nilai tertinggi sebelum pandemi adalah sebesar 1,32E13, sedangkan angka transaksi harian maksimal selama pandemi justru meningkat tajam menjadi 4,04E13.

Dari data yang telah dikumpulkan, nilai perdagangan harian tertinggi pada masa sebelum pandemi terjadi pada tanggal 20 Desember 2019 sebesar Rp. 13.913.783.550, sedangkan nilai perdagangan harian tertinggi pada masa pengamatan selama pandemi terjadi pada tanggal 20 Mei 2020 meningkat tajam yaitu sebanyak Rp. 40.418.496.532.116. Lonjakan nilai transaksi pada tanggal 20 Mei 2020 ini terjadi pada hari terakhir transaksi sebelum hari libur bursa untuk memperingati hari kenaikan Yesus Kristus dan Hari Raya Idul Fitri dari tanggal 21 Mei 2020 sampai dengan 25 Mei 2020. Transaksi dibuka kembali pada tanggal 26 Mei 2020.

\section{Nilai minimum perdagangan}

Nilai minimum adalah transaksi harian terendah dalam masa sebelum dan selama pandemi. Nilai transaksi terendah juga mengalami peningkatan dari semula sebelum ada pandemi adalah sebesar 4.17E12, tetapi pada masa pandemi justru mengalami peningkatan menjadi 5,18E12.

Dari data yang telah dikumpulkan, nilai perdagangan terendah pada masa selama pandemi adalah sebesar Rp. 5.175.132.682.219 yang terjadi pada tanggal 19 Maret yang jatuh pada hari Jumat sedangkan nilai perdagangan terendah pada masa sebelum pandemi adalah Rp. 4.173.936.847.583 yang terjadi pada tanggal 2 Januari 2020 yang jatuh pada hari Selasa.

\section{Nilai rata-rata}

Nilai rata-rata perdagangan juga mengalami peningkatan. Dari tabel distribusi frekwensi yang diolah dengan program SPSS, rata-rata nilai perdagangan harian pada masa pengamatan sebelum pandemi sebanyak $7.0250 \mathrm{E} 12$, tetapi pada masa pandemi justru mengalami peningkatan menjadi 8,0551E12.

Penghitungan rata-rata dengan menggunakan program excell diketahui bahwa rata-rata nilai perdagangan pada masa pengamatan sebelum pandemi adalah sebesar Rp. 7.024.962.867.854, sedangkan pada masa selama pandemi rata-rata meningkat menjadi 8.055.127.439.190.

Angka-rata-rata diperoleh dari pembagian total nilai perdagangan dengan jumlah hari pengamatan. Pada masa sebelum pandemi, total nilai transaksi adalah sebesar 428.522.734.939.093 yang tersebar pada 61 hari pengamatan. Sehingga rata-rata nilai transaksi dalam satu hari adalah 7.024.962.867.854. Sedangkan rata-rata nilai transaksi harian pada masa selama pandemi adalah 8.055.127.439.190, dari total nilai 
perdagangan sebelum pandemi sebesar Rp. 467.197.391.473.019 dibagi dengan 58 hari pengamatan.

\section{Kurs}

Di sisi lain, nilai pertukaran rupiah terhadap USD atau kurs justru mengalami pelemahan atau depresiasi. Kurs terendah selama masa pengamatan sebelum pandemi adalah sebesar Rp 9.085, sedangkan kurs terendah selama pandemi adalah Rp. 14.168.

Dari grafik kurs dapat dilihat bahwa kurs sebelum pandemi cenderung stabil pada angka terendah Rp. 9.085 dan tertinggi 9.753 sehingga rentang antara nilai tertinggi dan terendah hanya terpaut Rp. 668. Pada tanggal 28 Februari atau akhir pengamatan sebelum terjadi pandemi, nilai tukar rupiah terhadap USD adalah Rp. 9.336. Tetapi selang tiga berikutnya yaitu tanggal 2 Maret 2020 atau awal masa pandemi, nilai rupiah terpuruk di angka Rp. 14.413. Selama masa pandemi, nilai tukar rupiah terus mengalami depresiasi hingga puncaknya adalah pada hari ke 23 masa pandemi yaitu pada titik Rp. 16.741 yang terjadi pada tanggal 2 April 2020. Rentang angka terendah dan tertingi pada masa pandemi terpaut sebesar Rp. 2.573. Rentang yang sangat tinggi bila dibandingkan dengan pengamatan sebelum pandemi yang hanya mempunyai rentang sebesar Rp. 668. Setelah kurs tertinggi pada hari ke 23 atau tanggal 2 April 2020 tersebut, rupiah berangsur-angsur menguat hingga mencapai Rp. 14.733 pada pengamatan terakhir masa pandemi, yaitu pada hari ke 58 atau tanggal 29 Mei 2020.

\section{KESIMPULAN}

Pandemi covid 19 memberikan dampak yang luar biasa pada perekonomian di seluruh dunia. Dampak tersebut antara lain:

1. Pandemi covid mengubah pengaruh signifikan antara kurs terhadap nilai perdagangan di BEI menjadi tidak signifikan. Sehingga pada masa pandemi kurs tidak bisa dijadikan sinyal naik atau turunnya nilai perdagangan efek di BEI secara keseluruhan.
2. Pandemi covid 19 mendegredasi nilai mata uang rupiah terhadap USD

3. Nilai perdagangan efek di BEI pada saat pandemi justru mengalami peningkatan.

\section{DAFTAR PUSTAKA}

Ardelia Rezeki Harsono, \& Worokinasih, S. (2018). Pengaruh Inflasi, Suku Bunga, Dan Nilai Tukar Rupiah Terhadap Indeks Harga Saham Gabungan (Studi pada Bursa Efek Indonesia Periode 2013-2017). Jurnal Administrasi Bisnis (JAB), 60(Juli).

Firhan, A., \& Suhadak, F. (2019). Pengaruh Depresiasi Rupiah Terhadap Perdagangan Pasar Modal Dan Kinerja IHSG (Studi pada Bursa Efek Indonesia Periode 2013-2017). Jurnal Administrasi Bisnis (JAB), 72(2).

Ika Alivia Rizky, M. A., M. Cholid Maward. (2019). Pengaruh Nilai Tukar, Suku Bunga Sbi, Inflasi, Dan Pertumbuhan GDP Terhadap Pergerakan IHSG Di Bursa Efek Indonesia. JRA, 08(Februari).

Kewal, S. S. (2012). Pengaruh Inflasi, Suku Bunga, Kurs, dan Pertumbuhan PDB Terhadap Indeks Harga Saham Gabungan Jurnal Economia, 8(April).

M. Fauzan, \& Suhendro D. (2018). Pengaruh Kurs Rupiah Dan Right Issue Terhadap Harga Saham PT. Telekomunikasi Indonesia TBK yang Listing di Jakarta Islamic Index. Prosiding SENDI.

Mifta Indriati, Vaya Juliana Dillak , \& Zulistina., D. (2019). Pengaruh Inflasi, Nilai Tukar Rupiah, Tingkat Suku Bunga Dan Pertumbuhan Ekonomi Terhadap Indeks Harga Saham Gabungan Di Bursa Efek Indonesia Periode 2009-2018. Jurnal Akuntansi, Audit dan Sistem Informasi Akuntansi, 3(2).

Munawaroh, H., \& Handayani, S. R. (2019). Pengaruh BI Rate, Kurs Rupiah, 
Tingkat Inflasi, Harga Minyak Dunia, Harga Emas Dunia Terhadap Indeks Harga Saham Gabungan (IHSG) (Studi pada Perusahaan yang Terdaftar Di Bursa Efek Indonesia Periode 2013-2018). Jurnal Administrasi Bisnis (JAB), 72(1).

Nidianti, E., \& Wijayanto, E. (2019). Analisis Pengaruh Kurs, BI Rate dan Inflasi Terhadap IHSG di BEI Periode 20142017, Keunis Majalah Ilmiah, 7(1).

Palatte, M. H., \& Akbar. (2014). Pengaruh Nilai Tukar Mata Uang Dan Tingkat Suku Bunga Terhadap Perkembangan Indeks Harga Saham Gabungan Di Bursa Efek Indonesia Periode 20092013. Jurnal Manajemen, Vol. 01 (02).

Ratna, M., Topowijono, M. G., \& Sulasmiyati, S. (2016). Pengaruh Tingkat Suku Bunga, Nilai Tukar Dan Inflasi Terhadap Harga Saham (Studi Pada Sub-Sektor Perbankan Di Bursa Efek Indonesia Periode 2011-2015). Jurnal Administrasi Bisnis (JAB), 35(2).

Sari, W. I. (2019). Analisis Pengaruh Inflasi, Suku Bunga SBI, Nilai Tukar Terhadap Return LQ 45 dan Dampaknya Terhadap Indeks Harga Saham Gabungan (IHSG) di Bursa Efek Indonesia (BEI). jurnal Sekuritas, 3(1).

Setiawan K., \& Mulyani E. (2020). Pengaruh Perubahan Nilai Tukar Rupiah, Tingkat Inflasi, dan Indeks Bursa Internasional Terhadap Indeks Harga Saham Gabungan (IHSG) di Bursa Efek Indonesia (BEI). Ecogen, Vol. 3 (1).

Sudirman. (2018). Pengaruh Perubahan Nilai Tukar Rupiah Tengah US Dollar Terhadap Indeks Harga Saham Gabungan (IHSG) Di Bursa Efek Indonesia. Jurnal Al-Buhuts Volume, 1(1). 